\title{
POSTAĆ JANA PAWŁA II W DRAMACIE NAJNOWSZYM
}

W polskim piśmiennictwie krytyczno-naukowym zdecydowanie przeważa refleksja nad twórczością literacką Karola Wojtyły nad badaniami poświęconymi utworom, w których polski Papież pojawia się jako bohater literacki, zauważa Krzysztof Dybciak (,Jan Paweł II jako postać literacka” 83 n.), twórca cennej antologii zbierającej wartościowe artystycznie teksty literackie o polskim Papieżu. Twórczość dramatyczną reprezentuje w niej jedynie fragment sztuki Jerzego Pilcha Narty Ojca Świętego zrodzonej z potrzebnych, a jakby w literaturze nieobecnych, pytań o wpływ Jana Pawła II na współczesnego człowieka. Pisał o tym Pilch w przedmowie do sztuki:

[Jan Paweł II] jest, jak wszyscy wiedzą, jedną z pierwszych postaci, jakie dzisiejszą Polskę ukształtowały i po prostu stworzyły. Nie mówię, że dotykam tematu papieskiego z jakiegoś obywatelsko-artystycznego obowiązku, choć nieobecność tego tematu w dzisiejszej sztuce, zwłaszcza w sztuce wysokiej, jest zdumiewająca. Nie mam najmniejszej iluzji, że lukę tę zapełniam, co więcej, nie chcę jej zapełniać. Nie pytam o papieża. Pytam o ludzi. (7)

Artykuł nawiązuje do postulatów badawczych Krzysztofa Dybciaka i do jego refleksji o Papieżu w literaturze, która stała się w tym miejscu cenną inspiracją. Podejmuje próbę odpowiedzi na pytanie o sposób ukazania osoby, życia i dzieła Jana Pawła II w wybranych tekstach dramatycznych, w których postać Papieża się pojawia, choć nie pełni w nich roli pierwszoplanowej, i o jej oddziaływanie w świecie przedstawionym. Ograniczony wąskimi ramami artykułu przegląd, rozpoczyna opisywane już w innym miejscu ujęcie Pilcha (Tomasik; Kozłowska; Dziewulska), w którym procesowi tworzenia papieskiego mitu towarzyszy dramat wymazywania

Dr hab. JoAnNA MichaLCZUK - adiunkt Katedry Dramatu i Teatru w Instytucie Literaturoznawstwa KUL; adres do korespondencji: Katolicki Uniwersytet Lubelski Jana Pawła II, Al. Racławickie 14, 20-950 Lublin; e-mail: joanna.michalczuk@kul.pl. ORCID: http://orcid.org/0000-0001-6809-0952. 
realnej obecności Papieża, ujęcie przywołane tu raz jeszcze, ze względu na znaczenie uchwyconych w nim zjawisk. Przedmiotem uwagi staje się również dramat Artura Grabowskiego Cnoty zachodniej cywilizacji, powstały już po śmierci Jana Pawła II, w latach 2006/07, w którym sposób ukazania Papieża - tu pojawiającego się epizodycznie, w jednej ze scen, wpisuje się w diagnozę poważnego kryzysu antropologicznego i duchowego współczesnego człowieka. Inne ujęte w artykule teksty to Dotknięci Pawła Grabowskiego i Człowiek z Bogiem w szafie Michała Walczaka, napisane na konkurs na dramat inspirowany życiem, myślą i twórczością Jana Pawła II, ogłoszony przez Centrum Myśli Jana Pawła II w Warszawie, opublikowane wraz z pozostałymi wyróżnionymi wówczas sztukami w zbiorze Mrok jak światto. W tekstach tych postać Papieża - przywoływana we wspomnieniach i relacjach innych bohaterów - wpływa na ich życie, w sposób istotny je zmieniając, nawet jeśli sami nie do końca są tego świadomi.

Komediowe ujęcie Pilcha służy odsłonięciu - analizowanego już - obrazu polskiego katolicyzmu (Dejnek 302 n.). Obraz ów staje się literacką egzemplifikacją zdefiniowanej przez Piotra Kowalskiego „potocznej” religijności - przeciętnej, standardowej, podlegającej „,mechanizmom myślenia potocznego”, familiaryzującej przeżycia religijne (106). „Potoczna” religijność stapia się tu z polską skłonnością do megalomanii i do popadania w skrajności, wyeksponowaniu ich służy zaś sytuacja alkoholowej biesiady, podczas której pojawia się temat papieski, służy jej także zestaw cech bohaterów podkreślający predylekcję postaci do ulegania nierealistycznym wizjom, ale i nałogi (zwłaszcza pijaństwo) bohaterów. Sposób i okoliczności przedstawienia postaci przekładają się na ich ograniczoną - już w punkcie wyjścia - wiarygodność, co z kolei wpływa na znaczenie zgłaszanych przez nich moralnych dylematów. Wyłaniający się z rozmów mieszkańców Pilchowych Granatowych Gór proces kreacji postaci Papieża wpisuje się w charakterystyczne dla kultury popularnej zjawisko poszukiwania przez odbiorcę wzorca, idola (Fiała, Fitas i Skórczewski 5 n.; Plucińska 212). Wiąże się zarazem z, wyraźnie obecnymi w tekście Pilcha, bliskimi „potocznej” religijności w świecie zacierających się granic między religią a kulturą popularną, choć samo zjawisko przenikania się tych rzeczywistości odczytywać można jako zjawisko pozytywne (Dybciak, „Pokolenie Jana Pawła II” 187 n.), tendencjami do infantylizacji i familiaryzacji obrazu polskiego Papieża. Wynikają one z prób dostosowania wyobrażenia o wielkości i świętości Papieża - głowy Kościoła katolickiego reprezentującego teologiczną wiedzę i rzeczywistość chrześcijańskiej aksjologii - do intelektualnych horyzontów i jakości moralnych rozpoznań Pilchowych bohaterów. Jan Paweł II jest przez nich postrzegany przede wszystkim jako człowiek, w którym zwykłość w zaskakujący sposób łączy się z wyjątkowością. Wymykająca się wszelkim schematom osoba Jana Pawła II tu ukazana jest w swojskim obrazie „emerytowanego pracownika bożego" (Pilch 36), który w Granatowych Górach 
mógłby prowadzić „tryb życia człowieka odpoczywającego” (Pilch 36), nieodbiegający znacząco od trybu życia innych starszych mieszkańców Pilchowego świata. W obrazie tym nierealistycznie ukazana fizyczność postaci nie odsyła do dramatu cierpienia i bliskości śmierci, podstawowymi rysami osobowości stają się zaś takie cechy, jak bezpośredniość, poczucie humoru, spontaniczność i skłonność do niekonwencjonalnych działań (w którą mógłby się wpisać pomysł papieskiego przyjazdu do Granatowych Gór), ale także miłość do gór i jazdy na nartach. Zwykłość postaci podkreśla też, stająca się częścią lokalnego mitu, reakcja młodego Karola Wojtyły na przepowiednię pontyfikalnej przyszłości, którą właśnie tu miał usłyszeć. Kreacja papieskiego obrazu - w wielokrotnie powtarzanych i dowolnie zniekształcanych opowieściach o rzekomym pobycie przyszłego Papieża w Granatowych Górach, nawiązuje zarazem do tendencji we współczesnej hagiografii, w której „nie chodzi o dyskusję na temat wartości uosobionych przez świętych i błogosławionych, lecz sposoby opowiadania o nich" (Kowalski 122). Tradycyjnie wiązaną z hagiografią cudowność czy heroiczność cnót Świętego ukazuje Pilch w sposób paradoksalny i parodystyczny, czyniąc je przedmiotem podobnie dowolnych przekształceń, jak czyni to z przestrzenią biblijnego słowa (Kulczycka 373 n.). To, co duchowe, ustępuje w Pilchowym świecie temu, co zmysłowe, papieska świętość przefiltrowana przez „potoczną" religijność bohaterów, ograniczona do ziemskiej perspektywy, przypomina sposób ujęcia świętości znany z dzieł kultury popularnej, ukazujących postaci aniołów, które wiodą ziemski żywot, przemawiają do wyobraźni masowego odbiorcy w zinfantylizowanej i zeświecczonej postaci, nie roztaczając niepokojących wizji nieznanej wieczności (Jarecka 164).

Takie pojmowanie papieskiej świętości czyni perspektywę życia „w blasku majestatu Następcy Świętego Piotra" (Pilch 32), przed którym nie ukryje się żaden grzech, możliwą do zaakceptowania: „nie duch świetlisty, nie anioł skrzydłami szumiący, nie bóstwo blaskiem oślepiające do nas przyjedzie” (Pilch 36). „To prawda, Duchem Świętym napełniony następca apostołów i taki, co może z aniołami miał rozmowy, ale też człowiek. [...] Taki sam człowiek, jak my” (Pilch 36). Tak pojmowana zwykłość świętości nie przypomina oczywiście tej, o której mówił Jan Paweł II, wskazując na świętość jako powołanie uniwersalne, dostępne dla każdego, uwarunkowane jedynie całkowitym oddaniem swojego życia Bogu, sam też własnym życiem dawał jej świadectwo (Malik 222). W świecie bohaterów Pilcha czytelnym punktem odniesienia dla „papieskiej doskonałości” (Pilch 32) staje się wykreowana doskonałość popkulturowych bohaterów medialnych, zwłaszcza idoli sportowych. W znanej scenie monologu Profesora Chmielowskiego, cytowanej także we wspomnianej wcześniej antologii w opracowaniu Dybciaka (Jan Pawet II w literaturze polskiej 310 n.), świętość i heroiczność cnót Jana Pawła II zyskuje kształt piłkarskiej metafory, wskazując na opisywany przez badaczy (Pasek 164 n.; Draguła 197 n.) 
proces przenikania się w kulturze popularnej elementów potocznego doświadczenia religijnego i popularnego rytuału, jakim jest gra w futbol. Sugestywny, przerysowany obraz Papieża jako geniusza piłki nożnej, niezwykłego stratega grającego na każdej pozycji jednocześnie, obdarzonego nadludzką siłą, pozwalającą mu wyjść zwycięsko i bez cienia zmęczenia z każdego spotkania - to obraz stworzony przez „fanatyka futbolu” (Pilch 159), przemawiający zwłaszcza do tych, którzy poprzez udział w widowiskach sportowych realizują swoje człowieczeństwo (Pasek 164 n.; Draguła 197 n.). W ujęciu Pilcha postać Papieża - szczególna, niezwykła, wyrastająca ponad przeciętność mieszkańców Granatowych Gór - staje się nośnikiem symbolicznych znaczeń, wielkim reprezentantem wspólnoty narodowej, „duchowym wodzem”, zdolnym poderwać naród do „wielkiej przemiany” (Celeda 80), z drugiej jednak strony - ujmowana w sentymentalnych i stereotypowych obrazach - szybko powszednieje, znikając z pola widzenia kibicującego mu wcześniej thumu. Humorystycznie ujętej mitologizacji Papieża towarzyszy obnażany przez Pilcha dramat jego zapominania - uobecniony w metaforze malejącego Papieża w rozrastającym się oknie Pałacu Arcybiskupów przy Franciszkańskiej 3, tym samym, w którym Jan Paweł II pojawiał się podczas pielgrzymek. „Najsławniejsze okno świata” (Pilch 164) uczynione przez Papieża sceną jego wystąpień, samo, już bez aktora, teraz „przezroczystego jak powietrze" (Pilch 165), który scenę do istnienia powołał, staje się „przestrzenią i przedmiotem kultu” (Kosiński 46). Wymazywanie obecności Papieża dokonuje się także za sprawą medialnych kreacyjno-mitologicznych zabiegów, które wpisują się w konsumpcyjne wymagania odbiorców, utrzymując ich jednocześnie „we władzy ekranu” (Kisielewska 303 n.).

„Przestaliśmy go zauważać, przestaliśmy o nim myśleć” - pisał Pilch (165). W alegorycznej „tragedii elementarnej” Cnoty zachodniej cywilizacji Artura Grabowskiego Papież staje się jedynie jednym z wielu telewizyjnych obrazów. Tekst ten mówi o świecie tragedii niemożliwej, bo odrzucającym transcendencję i sprowadzającym całość ludzkich spraw do kwestii społeczno-ekonomicznych czy psychologicznych. Jednoczesność nadawanych tu z wielu źródeł różnych komunikatów medialnych i natychmiastowość dostępu do wciąż aktualizowanych i modyfikowanych treści, odbiera zdolność usłyszenia słowa i nadawania mu trwałego znaczenia, a wszechobecność ekranów anektuje realność słabych, zagubionych wśród obcych głosów i ekranowych obrazów, bohaterów o rozchwianej tożsamości. W jednej ze scen, która podejmuje polski wątek, rozmowie bohaterek towarzyszy obecny w tle, w przypadkowych migawkach z pasterki w Watykanie, wykadrowany obraz cierpiącej twarzy starego, schorowanego Papieża. Ów obraz zapisany w dramacie przypomina o papieskim cierpieniu i powolnym odchodzeniu na oczach całego świata, o obnażonej przed telewizyjnymi kamerami i milionami odbiorców na całym świecie cielesnej słabości Jana Pawła II, dotkliwie odczuwanej przezeń starości i bezradności 
związanej z utratą dawnych sił. Unaoczniana przez media bliskość śmierci Papieża budzi postaci Grabowskiego z odrętwienia, w jakim trwają, wiodąc egzystencję przed ekranem. Przywołuje odległe wspomnienia papieskich pielgrzymek, rodzi lęk przed trwałą zmianą rzeczywistości, ale też pewnego rodzaju zdziwienie, że zmiana ta musi nastąpić. Zdziwienie to koresponduje ze słowami z Pilchowego tekstu: „Był jakby od zawsze i chyba wszystkim się zdawało, że będzie zawsze" (165). W rozmowie bohaterek Grabowskiego pojawia się jakby oczekiwanie na jakąś przemianę w tych wszystkich, którzy niegdyś towarzyszyli Papieżowi podczas jego pielgrzymek: „,co by to było?” („Cnoty zachodniej cywilizacji” 104), „Coś by musiało być. Te tłumy, co przychodziły, i w ogóle. Sama, jeszcze w szkole, stałam pod oknem. Wszyscy szli'" (104), „Stary jest, to prawda. Dziwnie jakoś będzie...” (104). Paradoksalnie, ów telewizyjny obraz cierpiącego Papieża w tekście Grabowskiego uświadamia bohaterce wpisaną w ludzką kondycję kruchość i śmiertelność, tak skutecznie unieważnianą przez cyberkulturę. Przeszywające trwogą umieranie Papieża staje się treścią snu bohaterki, o którym w dramacie opowiada, a który przypomina jej o rzeczywistym - bez pośrednictwa medium - istnieniu i rzeczywistym istnienia tego kresie. Ów sen rodzi w niej lęk związany z poczuciem własnej bezradności. „Śniło mi się... Wtedy, co tak się bałam, że umrę... Widziałam go jak umiera... Wyglądało jakby wyszedł z kadru. Ale tak jakoś... Jakby przez tylną ścianę" (104). Obecność postaci Papieża - w telewizyjnym obrazie i we śnie bohaterki - budzi niepokój i podszytą niepokojem świadomość rozróżnień między tym, na co patrzą postaci, a tym, co rzeczywiście istnieje, rozróżnień, które utraciły swoją oczywistość w kulturze totalnie mediatyzującej istnienie, sprowadzającej parametry ontologiczne do utożsamień z nieobecnym, z symulakrem bycia (Zawojski 423). Świadectwo cierpienia Papieża przenika do bardzo odległego od sfery religijności chrześcijańskiej świata myśli i uczuć postaci właśnie za pośrednictwem mediów, mogących przecież także odgrywać pozytywną rolę, czego obecny w kulturze medialnej Papież był świadomy. Działanie obrazu nie pozostawia jednak trwałych konsekwencji w rzeczywistości bohaterów „tragedii elementarnej”, bo w świecie odcinającym się od tego, co realnie istnieje, także wtedy, gdy wykracza poza poznanie zmysłowe, trwałych konsekwencji mieć nie może. „Nie ma takiej śmierci, której byśmy nie przeżyli” (104) - mówi postać Grabowskiego w kontekście przybliżającej się nieuchronnie śmierci słabnącego Papieża, wskazując zarazem na kondycję współczesnego człowieka, który przeżywa (każdą) śmierć, w istocie jej nie przeżywając, tak jak nie przeżywa własnego życia, w istocie nie żyjąc naprawdę. Rezygnując z prawdziwego bycia na rzecz bycia pozornego - w obecności medium i poprzez medium (Zawojski) ulega on jedynie złudzeniu doświadczania i przeżywania.

W odmienny sposób postać polskiego Papieża ukazują teksty zamieszczone w antologii Mrok jak światło, w których współistnieją dwa przeciwstawne elemen- 
ty: polemiczny, a nawet prowokacyjny wobec życia i działalności Jana Pawła II, związany z odczuciem absurdalności świata niedającego się pogodzić z papieskim przesłaniem, i nawiązująca do nauczania Jana Pawła II poważna refleksja nad problemem miłosierdzia Boskiego i ludzkiego (Mizera 10). W dramacie Walczaka Człowiek z Bogiem w szafie relacje i wspomnienia dotyczą papieskich pielgrzymek do Polski, nie zawsze głęboko przeżywanych, nie dla każdego i nie zawsze stających się głębokim przeżyciem duchowym. Sztuka Grabowskiego odsłania świat bohaterów dotkniętych społecznym wykluczeniem i w sposób szczególnie śmierć Jana Pawła II przeżywających, dotkniętych ową śmiercią. W obu dramatach pojawia się wyobrażenie upragnionego, od dawna wyczekiwanego, przełomowego dla bohaterów spotkania z Ojcem Świętym.

Sztuka Walczaka przypomina o fenomenie niezwykłej popularności Papieża inaczej niż tekst Pilcha. Przywołując postać Papieża-pielgrzyma w wypowiedziach postaci, odsłania zarazem zewnętrzne okoliczności papieskich spotkań, niedogodności towarzyszące pielgrzymom, utrudniające czy wręcz uniemożliwiające duchowe przeżycie, niekiedy także powierzchowność ich motywacji. Tekst Walczaka mówi też o tych, dla których, jak dla obojętnego religijnie bohatera o symbolicznym imieniu Adam i znaczącym nazwisku Brak, przekręcanym w dramacie na nie mniej wymowne: Wrak, rzeczywistość pontyfikatu Jana Pawła II była dość odległa. Odsłania jednak także prawdę o miłości, jaką Papież zyskiwał swoim sposobem bycia i sposobem głoszenia Słowa, o nadziei, jaką budził we wszystkich, którzy szukali nadziei, o przywracaniu wiary w sens istnienia, jaką dawał tym zwłaszcza, którzy czuli się odrzuceni i samotni w swoim cierpieniu. W losach bohatera dramatu pozwala dostrzec paradoksalną logikę Boskiego miłosierdzia, którego orędownikiem był Jan Paweł II. Czas wydarzeń w dramacie obejmuje kilkanaście lat, które upływają pomiędzy kolejnymi pielgrzymkami Papieża Polaka do ojczyzny. Wspomniany, nastoletni w pierwszej scenie dramatu, Adam, odmawiający wówczas udziału w papieskich uroczystościach, w których uczestniczy niemal cała społeczność jego miasteczka, widzi w religijności swoich rodziców jedynie ,powierzchowną bogobojność” (Walczak 354). Papieskie przesłanie wydaje się dlań zupełnie niedostępne, co jest konsekwencją podejmowanych przez niego wyborów. Przyjazd Jana Pawła II do kraju staje się dla bohatera dramatu Walczaka jedynie pretekstem do zaaranżowania pod nieobecność rodziców innego spotkania - z dziewczyną Kamą. Aksjologiczny chaos przekładający się na nieuporządkowanie w relacji bohaterów znajduje swoje odzwierciedlenie w wymieszaniu w scenie dramatu fragmentów transmitowanej Mszy świętej, celebrowanej przez Papieża, i opisu intymnego spotkania Adama i Kamy. Znaczenie kolejnej papieskiej pielgrzymki w dramacie, o której wszyscy mówią, że jest pielgrzymką ostatnią, podobnie jak tej ze sceny pierwszej, wiąże się dla bohatera wyłącznie z ponownym spotkaniem z dawno niewidzianą przezeń Kamą, które 
zapoczątkuje nowy etap przedwcześnie zerwanej relacji. Spotkanie to, tym razem przypadkowe, w Warszawie, paradoksalnie staje się możliwe dzięki owej papieskiej pielgrzymce, w której dziewczyna pragnie uczestniczyć. O obecności Papieża mówi też w dramacie Walczaka postać policjanta, rutynowo kontrolującego mieszkania, które, jak mieszkanie Adama, znajdują się na trasie papieskiego przejazdu. Przystająca do „potocznej” religijności, kolokwialna i mało przekonywająca zachęta do udziału w religijnych uroczystościach: „Nie za bardzo wyglądasz, chłopie. Weź się w garść. Idź na papieża. To pomaga. Byłeś kiedyś na papieżu?” (354) - zdradza naskórkowość motywacji i oczekiwań interlokutora Adama, nadającego spotkaniu z Janem Pawłem II charakter płytko, na poziomie emocjonalnym, pojmowanej terapii. Adam z dramatu Walczaka, stroniący od papieskich pielgrzymek, chowający się przed Papieżem w mieszkaniu, a w paradoksalny sposób doświadczający obecności Papieża w swoim życiu, paradoksalnie też sam zostaje przez Boga odnaleziony, gdy tytułowy Człowiek, sąsiad, prosi go, by „zaopiekował się” Bogiem z szafy. Ów proces opieki nad Bogiem wyrzuconym z ludzkiego życia, Stwórcą pozbawionym przez stworzenie prawa do istnienia, wymagający zgody Adama, otwiera przestrzeń na naprawcze działanie Boga w historii bohatera, także w owej zrywanej i odnawianej relacji, której bohater sam naprawić nie potrafi.

W przeciwieństwie do Adama Kobieta Bardzo Wierząca - bohaterka utożsamiająca się z wiarą, którą chętnie deklaruje - szuka Boga i pragnie spotkania z Ojcem Świętym, wiele sobie po spotkaniu tym obiecując. Owa postać z dramatu Walczaka teraz, po raz pierwszy i pewnie jedyny w życiu, ma szansę zobaczyć Ojca Świętego z bliska, choć, jak sama przyznaje, brała udział we wszystkich wcześniejszych papieskich pielgrzymkach do ojczyzny. Jej relacja oddaje atmosferę radosnego zbiorowego oczekiwania na przejazd wyjątkowego pielgrzyma, tworzy też dynamiczny obraz pielgrzymiego zgromadzenia. Ekscytacja towarzysząca niecodziennemu wydarzeniu miesza się tu bowiem z potęgującym się uczuciem rozdrażnienia spowodowanym upałem, brakiem miejsca w ściśniętym thumie i ograniczoną widocznością trasy przejazdu. Bohaterka z dramatu Walczaka gorączkowo próbuje „dostać się do przodu” (368), ,przedrzeć się bliżej ulicy” (369), do miejsca, z którego „Będzie najlepiej widać” (367). Wyraźną jej irytację, skutkującą natychmiastowym krytycznym osądem, rodzi zbyt głośna, jak ocenia, obecność czekającej na Papieża młodzieży: „Ci młodzi ludzie/ czy wiara musi ujawniać się/ tak hałaśliwie” (368). „Hałaśliwość/ Nie uważa pan/ Zagłusza wnętrze/ Potrzaskane wnętrza muszą mieć/ Ci młodzi ludzie" (368 n.). Zdenerwowanie bohaterki spowodowane jest też opóźnieniem godziny przyjazdu Papieża: „Ile jeszcze mamy czekać/ Brak kultury/ Coś się opóźnia/ Podobno spotkanie z prezydentem/ Się przeciągnęło” (367), „Czy ojciec święty przyjechał tu/ Dla prezydenta/ Skandal” (369). Kobieta Bardzo Wierząca, wbrew własnym deklaracjom: „wolę/ Ciszę/ W której można dopiero/ Zaznać radości obcowania/ Z najwyższym” 
(368), nie potrafi dać świadectwa swojej „Normalnej/ zdrowej wiary” (367) - jak sama ją określa, ale też w towarzyszących oczekiwaniu na Papieża okolicznościach wydaje się to bardzo trudne. Szansę na duchowe przeżycie przekreśla fala narzekań i pretensji, szansę na długo wyczekiwane spotkanie z Ojcem Świętym przekreśla zaś zupełnie niepotrzebny incydent $\mathrm{z}$ udziałem Kobiety i policjanta zapewniającego bezpieczeństwo na trasie przejazdu. Tracąc możliwość spotkania z Ojcem Świętym, traci „Wszystko” (377), widzi w nim bowiem jedynego człowieka, którzy może jej pomóc odzyskać poczucie znaczenia własnego życia. Choć nazywa siebie „bardzo wierzącą”, w istocie pragnie cudu utwierdzającego ją w przekonaniu, że Bóg naprawdę jest, cudu, którego mogłaby doświadczyć za pośrednictwem osoby Papieża, jego uśmiechu, gestu czy słowa. To, co okazuje się niemożliwe podczas krótkiego przejazdu Ojca Świętego, staje się przedmiotem projekcji bohaterki Walczaka. Postać tworzy zatem poprawioną przez siebie historię papieskiego spotkania z pielgrzymami, które staje się spotkaniem twarzą w twarz Papieża i dostrzeżonej przezeń w thumie Kobiety Bardzo Wierzącej, historię niezwykłą i nieprawdziwą: „Ojciec święty podszedł do mnie i zapytał/ Skąd ma pani taki piękny kapelusz” (387), „A ja powiedziałam/ To kapelusz mojej babki/ Skłamałam to prawda/ Ze zdenerwowania/ Nie powiem przecież ojcu świętemu/ Że znalazłam go na śmietniku" (389). Historia ta jednak, choć się nie wydarzyła, wydarzyć się mogła, Papież był bowiem „Fantastycznym człowiekiem/ Świętym/ A jednak niepozbawionym dowcipu/ Ludzkim po prostu" (388) - jak mówi bohaterka, w istocie bardzo zwyczajna w owym pragnieniu najważniejszego, osobistego spotkania, przemieniającego rzeczywistość jej samotnego i smutnego życia. Jan Paweł II z opowieści Kobiety zagubionej we współczesnym świecie i w szukaniu Boga, ale „bardzo wierzącej” w wiarę Papieża, to postać ujmująca - uśmiechem, dowcipem, otwartością i bezpośredniością w kontakcie $\mathrm{z}$ drugim człowiekiem. Zauważająca tych, których nikt nie zauważa, pojmująca to, co dla innych niepojęte, doceniająca każdy dar, nawet najskromniejszy czy najbardziej nieoczywisty, jak ten, który przygotowała dla niego Kobieta. „Poszukuję prawdy proszę pana/ Prostych istotnych rzeczy/ [...] Dlatego tak kocham ojca świętego/ Można powiedzieć/ Że tylko jego rozumiem” (387 n.) mówi bohaterka stająca się w dramacie świadkiem siły oddziaływania papieskiego świadectwa, widząca w Janie Pawle II człowieka najbliższego, nie tylko dzięki niezwykłym cechom osobowościowym, ale w głoszonej przezeń Prawdzie, w którą wrosło papieskie życie i papieskie dzieło.

Czas wydarzeń Dotkniętych Pawła Grabowskiego rozpoczyna się 2 kwietnia 2005 roku, w dniu śmierci Jana Pawła II, a kończy przed papieskim pogrzebem. Miejscem wydarzeń jest jedno z polskich miast, w którym wyjątkowość chwili podkreśla niecodzienna sceneria: płonące w mroku światełka, tworzące „rzekę płomyków” (68). Tekst, mówiący o ludziach spontanicznie gromadzących się w kościołach i na ulicach, 
pragnących wspólnie przeżywać żałobę, nawiązuje do działań i wydarzeń towarzyszących śmierci Jana Pawła II, do - jak piszą niektórzy badacze (Kosiński 46 n.) - największego w XXI wieku polskiego dramatu wspólnotowego, wyrastającego ze spontanicznych, stopniowo porządkowanych zachowań i działań wpisujących się w polską tradycję żałobną, a podyktowanych silnie odczuwaną więzią emocjonalną i duchową ${ }^{1}$. W dramacie Grabowskiego czas wspólnie przeżywanej żałoby staje się czasem otwarcia na drugiego człowieka. Przejawia się ono w chętniej niż zazwyczaj okazywanym miłosierdziu (odpoczywający przed wejściem do kościoła bohater, nazwany Adamem, dostaje, ku swemu zaskoczeniu, jałmużnę), i w zainteresowaniu jego osobą i jego losem, skutkującym konkretną pomocą - znalezieniem dachu nad głową. Zawiązująca się w dramacie Grabowskiego w dniu śmierci Papieża znajomość pary bohaterów, noszących imiona pierwszych biblijnych rodziców, zaczyna się na stopniach kościoła. Śmierć Jana Pawła II oznacza „Koniec epoki” (69), a jednocześnie jest intymnym doświadczeniem straty, zmieniającym ludzi, zbliżającym ich do siebie, rodzącym poczucie wspólnoty. Nawet Adam, bohater z kryminalną przeszłością, dla którego praktyki religijne stanowiły jedynie rodzaj urozmaicenia więziennej egzystencji, zdobywa się na wyznanie: „w sumie obcy człowiek, właściwie go nie znałem, a jakbym stracił kogoś, ja wiem... bliskiego?” (90).

Postać polskiego Papieża pojawia się we wspomnieniach bohaterów zepchniętych poza margines życia społecznego, wegetujących w warunkach urągających ludzkiej godności, „dotkniętych” wykluczeniem, ale też śmiercią Papieża, której doświadczają bardziej może niż się tego spodziewali. Dla dwudziestokilkuletniej Ewy z dramatu Grabowskiego Papież - jak dla bohaterki z dramatu Walczaka - jest postacią najbliższą. Dziewczyna otacza się papieskimi wizerunkami, traktując te słabej jakości reprodukcje jak relikwie. Na jednym z nich - podniszczonej, wyciętej z gazety, czarno-białej fotografii Papież błogosławi tłumy, na innym - umieszczonym „w kiczowatej ramce-szopce albo na kawałku drewna" (77 n.) wisi różaniec, przypominając o tej ważnej dla Ojca Świętego modlitwie, szczególnie bliski dziewczynie jest zaś wizerunek Papieża chorego i niedołężnego. Borykająca się z nawarstwionymi, nierozwiązanymi problemami i wewnętrznymi zranieniami, Ewa żyje wspomnieniem osobistego spotkania z Papieżem. Bohaterka, która dość naiwnie pojmowaną wiarę łączy z myśleniem magicznym, łagodzącym ból rozczarowań, uparcie wraca do tamtej, najważniejszej chwili. Papież, znacząc krzyżyk na jej czole, wypowiedzieć miał wówczas skierowane tylko do niej słowa. Jest przekonana, że gdyby zdołała je usłyszeć, mogły one trwale zmienić rzeczywistość jej życia. Jak w sztuce Walczaka

\footnotetext{
${ }^{1}$ Pojęcie zbiorowej dramatyzacji, o którym pisze Dariusz Kosiński, nie wyczerpuje oczywiście opisu zjawiska, dotyka bowiem przede wszystkim aspektu społecznego.
} 
pojawia się pragnienie i oczekiwanie cudu za pośrednictwem Papieża, cudu, który nie następuje: „to była najlepsza okazja, żeby się zdarzył! Cud. Dlaczego nic się nie stało? Wszystko mogło się zmienić. Pan Bóg mógłby mnie mieć taką szczęśliwą. [...] Nie miałam pieniędzy, żeby jechać za papieżem. A chciałam. Chciałam Panu Bogu dać jeszcze jedną szansę" (100). Dziecięca wiara w na poły baśniowego Papieża z wyobrażeń - przypominającego postać $\mathrm{z}$ wymyślonej przez ojca dziewczyny opowieści, która to opowieść, wobec braku życiowych perspektyw, miała jej dać nadzieję i poczucie celu - stopniowo jednak dojrzewa. Wiarę w słowa traktowane jak zaklęcie, które ma przynieść określony skutek, zastępuje bowiem osobowa relacja z Bogiem, w której pojawia się przestrzeń zawierzenia. Bliski bohaterce w cielesnej słabości i w mężnym sposobie znoszenia cierpienia, Papież staje się dla niej czytelnym i najbardziej wiarygodnym znakiem obecności Chrystusa: „Jak już się wypłakałam, pomyślałam, że może Bóg chce mnie właśnie taką, wiesz, pękniętą" (101). Pokazując uobecniający Chrystusową Mękę krzyżyk przy różańcu, dodaje zaś: „On słaby. Papież słaby. Ja słaba” (101). Choć rzeczywistość cierpienia pozostaje dla niej niezrozumiała, patrzy na Chrystusa i na świadectwo życia Jana Pawła II, który jak Chrystus zaufał Bogu do końca: „Tylko ufam. Jak On” (101), i stara się ją zaakceptować. Pozbawiona ojcowskiej miłości w Papieżu odnajduje też wzór ojcostwa. Śmierć biologicznego ojca dziewczyny, przypadająca dokładnie w tym samym czasie co śmierć Jana Pawła II, rodzi w Ewie jedynie bunt, który wypływa z poczucia krzywdy. Odejście Jana Pawła II rodzi zaś autentyczny ból straty osoby bliskiej i pragnienie modlitwy, także dziękczynnej, ,za to, że był” (118). Czas żałoby po śmierci Papieża rozpoczyna w dramacie P. Grabowskiego trudny, rozciągnięty może na całe dalsze życie Ewy, proces przebaczenia ojcu, a tym samym wewnętrznego odrodzenia postaci. O przebaczeniu, które dokonuje się powoli, ale które dokonać się musi, paradoksalnie mówi jej w dramacie ten sam Adam, którego w dniu śmierci Papieża uratowała, przyprowadzając do noclegowni, ale też umożliwiając mu dostrzeżenie ważnego dla niej świata wartości, który stał się i jego światem.

Ukazana w Dotkniętych rzeczywistość ludzkiego upadku, materialnej i duchowej biedy, w której często dobre intencje nieokrzesanych bohaterów rozmijają się z brutalnością ich działań, językowej agresji towarzyszą zaś słowa wspólnie wypowiadanej modlitwy czy zasłyszanych fragmentów Pisma Świętego, nie pozostaje taka sama po śmierci Papieża. Ta zaś zmienia nie tylko ukazanych tu katolików, ale też postać muzułmanina, nazwanego w dramacie Czeczenem, który przyłącza się do wylegającego na ulice, opłakującego Papieża i modlącego się w jego intencji tłumu. Jego obecność nie jest tu przypadkowa, bohater ten przypomina w dramacie Grabowskiego o wydarzeniu, które niegdyś głęboko nim wstrząsnęło - o nabierającej wymiaru symbolicznego wizycie Ojca Świętego w więzieniu i przebaczeniu zamachowcowi, Ali Agcy. Z ukazanym w dramacie światem społecznie wykluczonych 
kontrastuje świat materialnego dostatku, o którym przypominają biznesmeni i ich ochroniarze, wkraczający do zajmowanej przez bezdomnych hali. Z jednakową pogardą traktują oni tymczasowych jej mieszkańców i rozmawiają o Janie Pawle II, przedrzeźniając przy tym mimikę Papieża i karykaturalnie naśladując wymuszone chorobą Ojca Świętego mimowolne drżenie jego dłoni. Zderzenie wypowiadanych przez jednego z biznesmenów ewangelicznych słów (Mk 14,42): „Wstańcie! Chodźmy!” (114), które stały się tytułem jednej z książek Jana Pawła II, i kontekstu ich wypowiadania w tekście Pawła Grabowskiego, nie tylko ich nie unieważnia, ale sprawia, że bardziej jeszcze słowa te i implikowane przez nie treści zwracają uwagę odbiorcy dramatu. Przypominają Chrystusowe wezwanie skierowane do szczególnie wybranych i umiłowanych uczniów, będących z Nim w ogrodzie Getsemani, a za Chrystusowym - wezwanie papieskie do odważnego wyjścia naprzeciw woli Bożej, nawet jeśli oznacza ono „czas próby, wielki wysiłek i bolesny krzyż” (Jan Paweł II 163). Jak podkreślał bowiem Jan Paweł II, dowodząc tej prawdy także przykładem własnego życia: „Boża miłość nie nakłada na nas ciężarów, których nie moglibyśmy unieść, ani nie stawia nam wymagań, którym nie moglibyśmy sprostać. Jeśli wzywa, przychodzi z konieczną pomocą" (163 n.). Grabowski, który mówi w swoim dramacie o końcu pontyfikatu i zamykającej się wraz z nim epoce, pozwala myśleć o przyszłości z nadzieją - na duchowe odrodzenie człowieka. Przestrzeń nadziei za każdym razem otwiera się bowiem wraz z podjęciem decyzji, by podnieść się z upadku, wejść na drogę przebaczenia, podjąć działanie, które stanie się postacią dobra.

„Teraz i w przyszłości głównym celem będzie przeciwdziałanie zapomnieniu lub tworzeniu stereotypów fałszywej pamięci” - pisał Krzysztof Dybciak, podkreślając, iż postać polskiego Papieża - także dzięki wysiłkowi artystów - winna pozostać dla „wspólnoty polskiej, europejskiej i chrześcijańskiej w wymiarze globalnym czołową postacią” („Jan Paweł II jako postać literacka” 96). Ważnym zadaniem badawczym pozostają zatem prace włączające się w nurt naukowej refleksji nad obecnością osoby i dzieła Jana Pawła II w literaturze współczesnej, obecności na różne sposoby w utworach literackich prezentowanej, odsłaniające zarazem wpływ wielkiego Papieża na mentalność zwykłego człowieka i jego życiowe wybory. W analizowanych w przedstawionym tu artykule dramatach owa - pojawiająca się w tle, przywoływana we wspomnieniach czy wyobrażeniach bohaterów - szczególna postać, bo wzorowana na realnie istniejącej, wpisanej w historię Polski i świata, osobie Jana Pawła II, w sposób istotny oddziałuje na rzeczywistość innych dramatis personae. Kreujący papieski mit bohaterowie Pilcha, którzy nie potrafią odnieść treści papieskiego nauczania do przestrzeni własnego życia, nie umieją trwale się zmienić, choć z obecnością Papieża wiążą pragnienie życia tego przemiany, ale już w tekstach Michała Walczaka i Pawła Grabowskiego spotkanie z Ojcem Świętym staje się dla postaci tych dramatów spotkaniem najważniejszym, przełomowym. 
Autor Dotkniętych, utrwalający w literackim obrazie pamięć zbiorowo przeżywanej w kraju żałoby, przypomina zarazem o spontanicznym charakterze podejmowanych wówczas działań i towarzyszącym im poczuciu szczególnej, wspólnotowej więzi, a zarazem prawdę o tym, jak bardzo i w jak różny sposób śmierć ta wówczas wielu „dotknęła”. Nawet w ujęciu Artura Grabowskiego, obnażającym rzeczywistość poważnego kryzysu antropologicznego i duchowego współczesnego człowieka znajdującego się w sytuacji ontologicznego zawieszenia, postać Papieża pojawiająca się na telewizyjnym ekranie, powracająca we śnie bohaterki, budzi tęsknotę za tym, co utracone, prowokując pytania o to, jak istnieje człowiek i po co istnieje. Postać Papieża ukazana jest w analizowanych dramatach w swojej fizyczności czasem nierealistycznie, jak u Pilcha, czasem boleśnie obnażonej przed kamerami coraz bardziej obojętnego świata, i poprzez niezwykłe cechy osobowościowe, które pozwalają widzieć w postaci tej wiarygodnego świadka Bożej miłości, łączącego w niepojęty sposób zwykłość ze świętością i w świętość wpisaną wielkość. Znaczenie Jana Pawła II w świecie przywołanych dramatów wiąże się z rolą głowy Kościoła katolickiego, z reprezentowaną przez Papieża wiedzą teologiczną i aksjologią, ze świętością na różne sposoby przez bohaterów pojmowaną, ale przede wszystkim - ze świadectwem życia w prawdzie i prawdą cierpienia, która - jak w dramacie Pawła Grabowskiego - przypomina o jego wymiarze transcendentnym. Odsłaniając ważną obecność Jana Pawła II w doświadczeniu zwykłego człowieka, teksty te w różny sposób mówią zarazem o współczesnym człowieku przeżywającym kryzys, pogłębiający się w zmediatyzowanym świecie. Prowokują istotne pytania - takie jak to o rolę mediów w kształtowaniu ludzkich postaw i współczesnym rozumieniu świętości, czy o jakość deklarowanej dziś wiary religijnej, ale też - o umiejętność rozpoznania przez człowieka XXI wieku jego roli w świecie, istotności i sensu jego istnienia w dobie nadmiaru i inflacji komunikowanych treści i proliferacji obrazów przesłaniających rzeczywistość. I skłaniają do refleksji nad tym, jak bardzo oddalił się on od źródła, o którym głoszonym słowem i świadectwem życia przypominał święty Jan Paweł II.

\title{
BIBLIOGRAFIA
}

\author{
PODMIOTOWA
}

Grabowski, Artur. „Cnoty zachodniej cywilizacji (tragedia elementarna)”. Artur Grabowski. Trzy, cztery - tragedia! Księgarnia Akademicka, 2015, ss. 7-120.

Grabowski, Paweł. „Dotknięci”. Mrok jak światto. Antologia dramatów inspirowanych życiem i twórczością Jana Pawła II, red. Michał Mizera, Centrum Myśli Jana Pawła II, 2007, ss. 63-118.

Jan Paweł II. Wstańcie, chodźmy! Wydawnictwo św. Stanisława BM, 2004. 
Jan Pawet II w literaturze polskiej. Antologia tekstów literackich, oprac. Krzysztof Dybciak, Centrum Myśli Jana Pawła II, 2008.

Pilch, Jerzy. Narty Ojca Świętego. Świat Książki, 2004.

Pilch, Jerzy. „Od autora”. Narty Ojca Świętego. Świat Książki, 2004, ss. 5-8.

Walczak, Michał. „Człowiek z Bogiem w szafie”. Mrok jak światto. Antologia dramatów inspirowanych życiem i twórczościa Jana Pawła II, red. Michał Mizera, Centrum Myśli Jana Pawła II, 2007, ss. 351-398.

\section{PRZEDMIOTOWA}

Celeda, Agnieszka. „Papież strzela gola”. Polityka, nr 47, 2004, ss. 80-81.

Dejnek, Katarzyna Anna. ,Narty Ojca Świętego, czyli katolicy w oczach Jerzego Pilcha”. Sacrum na nowo poszukiwane. O literaturze polskiej po roku 1989, red. Mirosława Ołdakowska-Kuflowa, Lech Giemza, Wydawnictwo KUL, 2015, ss. 299-320.

Draguła, Andrzej. Copyright na Jezusa. Język, znak, rytuał między wiara a niewiarą. Biblioteka „Więzi”, 2012.

Dybciak, Krzysztof. „Jan Paweł II jako postać literacka”. Karol Wojtyła - Jan Pawet II artysta słowa, red. Mirosława Ołdakowska-Kuflowa, Wojciech Kaczmarek, Wydawnictwo KUL, 2015, ss. 81-96.

Dybciak, Krzysztof. „Pokolenie Jana Pawła II - zjawisko religijne czy medialno-popkulturowe?”. Religijność w dobie popkultury, red. Tomasz Chachulski, Jerzy Snopek, Magdalena Ślusarska, Wydawnictwo UKSW, 2014, ss. 182-190.

Dziewulska, Małgorzata. „Mgła”. Dialog, nr 1, 2005, ss. 58-63.

Fiała, Edward, Adam Fitas i Dariusz Skórczewski. „Idol w kulturze - zarys problematyki”. Idol w kulturze, red. Edward Fiała, Adam Fitas, Dariusz Skórczewski, Wydawnictwo KUL, 2017, ss. 5-14.

Jarecka, Urszula. „Świeckie «Anioły». Wyobrażenia para-anielskie w kulturze popularnej”. Religijność $w$ dobie popkultury, red. Tomasz Chachulski, Jerzy Snopek, Magdalena Ślusarska, Wydawnictwo UKSW, 2014, ss. 146-172.

Kisielewska, Alicja. „We władzy ekranu”. Wiek ekranów. Przestrzenie kultury widzenia, red. Andrzej Gwóźdź, Piotr Zawojski, Wydawnictwo Rabid, 2002, ss. 303-314.

Kosiński, Dariusz. „Ku dramaturgii doświadczenia”. Dramatyczność i dialogowość w kulturze, red. Anna Krajewska, Danuta Ulicka, Piotr Dobrowolski, Wydawnictwo Naukowe UAM, 2010, ss. 40-50.

Kowalski, Piotr. Popkultura i humaniści. Daleki od kompletności remanent spraw, poglądów i mistyfikacji. Wydawnictwo UJ, 2004.

Kozłowska, Justyna. „Gdy struś zielony przechodzi”. Dialog, nr 1, 2005, ss. 52-57.

Kulczycka, Dorota. „«Lęk przed wpływem»? Kontr-obecność Biblii w «Monologu z lisiej jamy» $\mathrm{i}$ «Nartach Ojca Świętego» Jerzego Pilcha”. Biblia w dramacie, red. Edward Jakiel, Wydawnictwo UG, 2018, ss. 373-392.

Malik, Jakub. „Hagiologia i hagiografia według Jana Pawła II”. Karol Wojtyła - Jan Pawet II artysta słowa, red. Mirosława Ołdakowska-Kuflowa, Wojciech Kaczmarek, Wydawnictwo KUL, 2015, ss. 215-235.

Mizera, Michał. „Oksymoron i miłosierdzie, czyli papieska inspiracja. Wprowadzenie”. Mrok jak światto. Antologia dramatów inspirowanych życiem, myśla i twórczością Jana Pawła II, red. Michał Mizera, Centrum Myśli Jana Pawła II, 2007, ss. 9-17.

Pasek, Zbigniew. „O duchowości w piłce nożnej, czyli Cracovia jako sens życia”. Katarzyna Skowronek, Zbigniew Pasek. Nowa duchowość w kulturze popularnej. Studia tekstologiczne. Wydawnictwo Libron, 2013, ss. 164-186.

Plucińska, Dorota. „Hagiografia we współczesnej kulturze popularnej: Jan Paweł II w konwencji humorystyczno-anegdotycznej («Kwiatki Jana Pawła II»)”. Religijność w dobie popkultury, red. Tomasz Chachulski, Jerzy Snopek, Magdalena Ślusarska, Wydawnictwo UKSW, 2014, ss. 211-229. 
Tomasik, Radosław. „Papież jak marzenie”. Czas Kultury: kultura, literatura, filozofia, nr 1, 2005, ss. $118-121$.

Zawojski, Piotr. „Monitory między nami. O byciu razem i osobno w cyberprzestrzeni”. Wiek ekranów. Przestrzenie kultury widzenia, red. Andrzej Gwóźdź, Piotr Zawojski, Wydawnictwo Rabid, 2002, ss. $423-431$.

\section{POSTAĆ JANA PAWŁA II W DRAMACIE NAJNOWSZYM}

$$
\text { Streszczenie }
$$

Artykuł stanowi propozycję przeglądu kilku wybranych, artystycznie wartościowych tekstów dramatycznych powstałych w pierwszym dziesięcioleciu XXI wieku, w których pojawia się, w różnych ujęciach, postać wzorowana na wyjątkowej osobie polskiego Papieża: Narty Ojca Świętego Jerzego Pilcha, Dotknięci Piotra Grabowskiego, Człowiek z Bogiem w szafie Michała Walczaka oraz tekstu Artura Grabowskiego Cnoty zachodniej cywilizacji. Zmierza do odpowiedzi na pytanie, jak osobę Jana Pawła II, jego życie i dzieło zapisała przywołana tu literatura, pokazując zarazem utrwalony w przestrzeni literackiej wpływ Ojca Świętego na zwykłego człowieka. Włączając się w nurt badan nad obecnością Jana Pawła II w tekstach literackich, wpisuje się zarazem w potrzebę ocalania pamięci o świętym papieżu.

Słowa kluczowe: Jan Paweł II; postać literacka; dramat polski

\section{THE PERSON OF JOHN PAUL II IN RECENT PLAYS}

\section{Su m mary}

This article analyses several artistically important Polish 21 st-century plays, in which a character has been modelled on the person of Pope John Paul II. The works studied here are Jerzy Pilch's Narty Ojca Świętego, Paweł Grabowski's Dotknięci, Michał Walczak's Człowiek z Bogiem w szafie and Artur Grabowski's Cnoty zachodniej cywilizacji. This article aims to show not only the way the above-mentioned literary texts present the figure of the Pope, his life and works, but also his influence on the life of ordinary people. By researching John Paul II's presence in literature, this article helps to contribute to the commemoration of the Pope Saint.

Keywords: John Paul II; literary character; Polish drama 